\title{
On Direct Object in Latin Impersonal Passive Constructions
}

\author{
Vlada A. Chernysheva
}

St. Petersburg State University, 7-9, Universitetskaya nab., St. Petersburg, 199034, Russian Federation; st042939@student.spbu.ru, chernyshe.va@mail.ru

For citation: Vlada A. Chernysheva. On Direct Object in Latin Impersonal Passive Constructions. Philologia Classica 2018, 13(2), 241-246. https://doi.org/10.21638/11701/spbu20.2018.205

\begin{abstract}
This article deals with the Roman grammarians' interpretation of impersonal passive constructions and verbal government. A direct object depending on impersonal passive verbs is unattested in Classical Latin, whereas it is possible in Early and Late Latin and is treated as a feature of colloquial language. I suppose that the passage concerning the passive verbs in Ars de nomine et verbo (GL 5. 372. 35-373. 20), written by the 5th-century A. D. grammarian Consentius, provides evidence for such a usage. The examples from Terence (per quem res geretur maxime), Cicero (rem agi), and Virgil (iam tempus agi res), the meaning of which remains unclear for Consentius, are discussed in this passage. Each of them contains a form of the noun res and passive-looking verb forms geretur and agi, which may have either passive or impersonal meaning. In the latter case the noun inevitably becomes a direct object. According to Classical Latin grammar rules, such an impersonal meaning is impossible, and, consequently, the forms of the noun res are subjects of the subordinate and infinitive clauses. The passage discussed in this paper should be included among other $5^{\text {th }}$-century Latin examples in which direct objects depend on impersonal passive verbs. Besides, the passage is remarkable from the standpoint of ascribing a colloquial feature to the standard classical texts which were read in Roman schools.
\end{abstract}

Keywords: Latin linguistics, impersonal passive, verbal government, direct object, Late Latin, Consentius, Roman grammarians.

Recently, the impersonal passive ${ }^{1}$ has become a widely discussed issue in Latin linguistics, and impersonality is being studied from various linguistic perspectives: pragmatic functions, verbal valency, agentivity, unergativity, and some others.

In many languages of the world, ${ }^{2}$ the impersonal passive verbs can take a direct object. As regards Latin, one cannot find instances of such constructions in the Classical Latin texts, ${ }^{3}$ but there are several examples of this kind in other periods of the Latin language.

On the basis of the six passages from the Early Latin authors, W. Lindsay argues that direct objects depending on impersonal passives existed in Early Latin and gives six examples. ${ }^{4}$ The same examples are given by A. Ernout in his study on the passive in the Latin language of the republican time. ${ }^{5}$ G. Calboli demonstrated that some of these examples

${ }^{1}$ Impersonal passive forms can be derived from intransitive verbs (e.g. itur, statur, sedetur) or transitive ones, taken absolutely (e.g. amatur, bibitur, estur). The term "impersonal passive" is not correct, because in fact, there is neither impersonal nor passive meaning in the forms mentioned above. Nevertheless, it is still used out of habit. On the term "impersonal" see also Pinkster 1992, 162-164.

${ }^{2}$ For example, in Dutch, German, Polish, Spanish, Ukranian etc. See Comrie 1977.

3 Pinkster 2015, 268.

4 Pl. Cas. 185; Mil. 24; 254; Pseud. 817; 1261; Ennius trag. 100 R. See Lindsay 1936, 53.

${ }^{5}$ Ernout 1908-1909, 290-291. 
had appeared due to the text corruption. ${ }^{6} \mathrm{M}$. Cennamo, following A. Rovai, analyses only four sentences ${ }^{7}$ : vitam vivitur (Enn. Trag. 202 Jocelyn) "one lives a life", pessumis me modis despicatur domi (Plaut. Cas. 185 Nixon) "one despises me at home in a very bad way", nilne te populi vereretur? (Atta com. 7 Ribbek) "don't you respect people?", item [ut] vasa vinaria et olearia potius faciendum (Varr. Rust. 1. 13. 1 Goetz) "to lay in jars of wine and oil".

The examples of "unusual" direct objects in Late Latin are discussed in detail by M.Cennamo. The reorganisation of the voice system, which took place in the 4th and 5 th centuries "in various areas of Romania", gave rise to different constructions with accusative subjects, for instance, anticausative constructions (multos languores sanantur... "several illnesses heal..."), impersonal passive constructions (cutem... esocis... non manducetur "the pike's shin should not be eaten") ${ }^{10}$ and some others.

As regards Roman grammarians, they argue that the impersonal passive verbs govern nouns or pronouns in oblique cases, for example, in the ablative:

etiam uerba inpersonalia, quae in tur exeunt, casui seruiunt ablatiuo, ut geritur a me a te ab illo. (638. 9-10 Holtz)

"The impersonal verbs, which end in tur, are also combined with the ablative case, for example, geritur a me a te ab illo."

In the passage cited above, personal pronouns are given to illustrate impersonal constructions where agents ${ }^{11}$ can be in each of the three possible persons, while the verb form is only in the third person singular. However, such complete constructions are rare in Latin. ${ }^{12}$

Another option is the dative case. If a verb can take an indirect object in dative, it also takes it when used as an impersonal form.

ea sunt quae datiuo casu cohaerunt, velut maledico tibi, invideo tibi, obicio tibi, consulo tibi, provideo tibi, impero tibi, noceo tibi. haec omnia in persona patientis non recte dicimus maledicor a te nec invideor a te sed maledicitur et invidetur mihi a te... (GL 1.399. 14-18)

"There are some verbs which combine with the dative case, as maledico tibi, invideo tibi, obicio tibi, consulo tibi, provideo tibi, impero tibi, noceo tibi. In case of the passive form, we should say maledicitur et invidetur mihi a te rather than maledicor a te, or invideor a te."

None of the Roman grammarians mention the accusative. The only work in which the accusative case is mentioned implicitly is the Consentius' Ars de nomine et verbo, where

${ }^{6}$ Calboli 1962, 26-27, 42-44.

(C) St. Petersburg State University, 2018

7 Cennamo 2011, 178.

8 This sentence is notable for two peculiarities. Firstly, the accusative te is not a direct object, as it may seem at first glance. $T e$ is an accusative of subject and expresses an experiencer ("also in impersonal construction with accusative of person feeling respect": OLD, s. v.), a fact which could have influenced the usage of the accusative of subject. Secondly, the verb vereor is a deponent verb, whereas impersonal passive forms usually come from active-looking verbs. Nevertheless, impersonal passives derived from deponent verbs are noted, for example, by grammarian Sacerdos: "criminatur a me, id est criminor, luctatur a me, id est luctor" (GL 6. 431.33-34), where agents (not experiencers) are expressed with the pronouns in ablative.

9 Cennamo 2011, 170-171.

10 Cennamo 2011, 173.

11 An agent can also be expressed with preposition per and accusative as in "per quem geretur maxime". Hartung 1975, 356.

${ }^{12}$ One example appears in Plautus. See Pinkster 2015, 269. 
quotes from Terence (Ter. Phorm. 28), Cicero and Virgil (Verg. Aen. 5. 638) are considered to be ambiguous in their meaning. This "Ars" belongs to the type of Schulgrammatik ${ }^{13}$ and aims at explaining texts which were read at school.

Ait Virgilius 'usque adeo turbatur agris' ${ }^{14}$ item Terentius 'per quem res geretur maxime'. Utrumque verbum inpersonale est, alterum praesentis temporis, futuri alterum. Sed huius verbi intellectum videamus. Quod ait Terentius 'per quem res geretur maxime' videamus quid dixerit geretur utrum ad rem an ad Phormionem ${ }^{15}$ referendum sit. Si ad Phormionem, qui acturus est, genus est inpersonale verbi ab activo modo, id est a gero geritur gerebatur gestum est gestum erat geretur. Si ad rem nos trahit intellectus, quae gerenda est, erit passivum verbum indicativi futuri, id est gerar gereris geretur. Simile ratione discutiamus et eam significationem, quam dixit Virgilius, 'usque adeo turbatur agris', et quid cui adplicari debeat discernamus. Ex hoc quidem intellegimus plerumque concurrentes significatus duas figuras exhibere, passivam et activam. Aliud autem esset, si aut ille non adiecisset res aut ille agris. Haec duplex intellegentia etiam in infinitivo modo evenit. Ait Cicero 'rem agi'; ${ }^{16}$ dicit item Virgilius 'iam tempus agi res. ${ }^{17}$ In hoc si ipsam vocem attendamus, agi venit ab infinitivo modo passivo, id est ab agor ageris agitur, in infinitivo facit agi; si vero eos contemplemur, per quos agitur, venit a verbo impersonali agitur, cuius origo ab activo manat, id est ab ago agis agit, quod per omnes rursus modos declinatum facit infinitivum modum sic agi actum esse actum iri. (GL 5. 372. 35-373. 20)

"Virgil says usque adeo turbatur agris, the same Terence per quem res geretur maxime. Both verbs are impersonal, the first one being in the present tense while the second one in the future. But let us observe the meaning of this verb. As regards the Terence' 'per quem res geretur maxime', let us observe whether he refers geretur to res or to Phormio. If to Phormio, who will be acting, the voice of the verb is impersonal, derived from active mode, i.e. from gero geritur gerebatur gestum est gestum erat geretur. If the meaning refers to the affair, which should be carried out, it will be a passive verb in the future indicative form, i.e. gerar gereris geretur. In a similar way let us discuss also the meaning which Virgil has expressed in usque adeo turbatur agris, and let us define what has to be attributed to what. The two constructions, i.e. the passive and the active ones, as we see, display the competing meanings. It would be different yet, if one hadn't added res or another $<$ hadn't added $>$ agris. This double meaning also occurs in the infinitive mood. Cicero says rem agi, the same Virgil: iam tempus agi res. Here, if we draw attention to the very word, agi comes as passive infinitive form, i.e. the infinitive from agor ageris agitur is agi. If we observe indeed, who is acting, <agi is derived from the impersonal verb agitur, which derives from the active mode, i.e. from ago agis agit, whose infinitive is declined in all possible ways as follows: agi actum esse actum iri."

Let us focus on the most significant points of the passage under consideration. In the clause "per quem res geretur maxime", the nominative singular noun res is the subject of

13 Law 1987, 196.

14 Verg. Ecl. 1. 11-12 Mynors: Non equidem invideo, miror magis: undique totis / usque adeo turbatur agris. ("I don't envy, indeed, I am rather astounded, all the fields are still in trouble.")

15 Ter. Phorm. 27-29 Kauer: quia primis partis qui aget is erit Phormio / parasitu', per quem res geretur maxume, / voluntas nostra si ad poetam accesserit (“...because the one who will play the principle part will be the parasite Phormio, through whom the affairs will be carried out at most, should our favour go to the poet.")

16 The collocation rem agi, with the word order like this, is not found in any extant work by Cicero, whereas agi rem appears once: deinde eandem aut consimilem aut maiorem aut minorem agi rem in praesenti demonstrare (Cic. Inv. 1. 24. 17).

17 Verg. Aen. 5. 638-639 Mynors: iam tempus agi res, / nec tantis mora prodigiis / ("it is time to get things done, no delay, when such signs are given.") 
the sentence and agrees with the verb geretur. In the two AcI constructions "rem agi" and "iam tempus agi res", the accusative singular rem and the accusative plural res are acting as logical subjects. From the viewpoint of Classical Latin grammar, none of them could be considered as a direct object governed by the verbs geretur and agi. Consentius, however, notices double meaning (duplex intellegentia) and two constructions (duas figures): passive and active. Although he does not claim in an explicit way that res or rem are direct objects, we can assume it from the passage. The verbs geretur and agi are treated in two different ways: as passive and impersonal ones, the latter derived from the active "mode" (venit ab activo modo). Significantly, the verb geretur is included among the impersonal forms (geritur, gerebatur, gestum est, gestum erat), and the verb agi goes back to the form agitur. Each of them is the third person singular. To sum up, the grammarian suggests that geretur and agi are impersonal passives like turbatur and, obviously, the constructions are subjectless, so that the nouns res and rem cannot be subjects: they are direct objects.

It is noteworthy that Consentius lived in the time of the Late Roman Empire, in the 5th century A. D., and came from Gallia Narbonensis. ${ }^{18}$ It seems that Consentius has carried over a colloquial feature of his day to the ancient classical texts, because he did not even admit that his own interpretation is rather colloquial or inappropriate for Classical Latin. As M. Cennamo has demonstrated, impersonal constructions with accusative were attested inter alia in Gaul of the 6th century. ${ }^{19}$ The contemporaries of Consentius, the readers of Ars de nomine et verbo probably did not consider this duplex intellegentia to be incorrect. Otherwise, Consentius would not have explained such ideas for the general public. This passage definitely proves that impersonal constructions with direct object did exist in Late Latin. Without any doubt, Terence, ${ }^{20}$ Vergil and Cicero did not put across any impersonal meaning in such constructions.

Ars de nomine et verbo stands out among other grammatical sources which deal with impersonal verbs, such as treatises written by Charisius, Diomedes, Donatus and Priscian. One of them is frg. Bobiense de verbo, where examples with an impersonal verb and accusatives are discussed. The passage below concerns the distinctions between the two moods: infinitive and impersonal. ${ }^{21}$ In order to show the difference, the anonymous grammarian gives examples of personal (legi Ciceronem, legi Sallustium) and impersonal (legi) passive infinitives:

haec erit discretio si dixero legi Ciceronem legi Sallustium infiniti est si vero tantummodo legi impersonalis est. non enim hunc aut illum intelligitur, sed ipsa qualiscumque lectio demonstratur. (47, 15-18 Passalacqua)

"The difference will be as follows: if I say legi Ciceronem legi Sallustium, it is an infinitive, if only legi, impersonal. It does not mean that one or another <author> is read, but the reading itself is meant."

18 Goetz 1900, 911-912.

19 For instance, in the Gallic inscription lapide $(m)$ non revolvatur, where lapide $(m)$ is an accusative argument and revolvatur is an impersonal passive. See Cennamo 2011, 184-185.

20 W. Lindsay found no examples of direct objects with impersonal passives in the comedies by Terence, which is not the case in Plautus.

21 Some artes grammaticae place impersonality into the grammatical category of mood (Instituta atrium: GL 4. 155. 37-156. 3), Cledonii ars (GL 5. 16. 19-20), Excerpta de Scauro et Palladio (GL 7, 344, 13-14)), the other sources claim that the voice of the verb can be impersonal, while the mood cannot (Ars grammatica by Sacerdos: GL 6, 429, 27), Charisius (Barwick 210, 67), Diomedes (GL 1. 336. 5-8), Donatus' Ars minor (Holtz 591, 9-11), Consentius' Ars de nomine et verbo (GL 5. 70. 24- 28). 
As we can see, the anonymous author of this work on Latin grammar ascribes impersonal meaning is ascribed only to the latter form (i.e. legi), whereas the former constructions (i. e. legi Ciceronem legi Sallustium) are undoubtedly treated as personal ones, Ciceronem and Sallustium being logical subjects of AcIs and not direct objects.

To conclude, the unique passage from Consentius' Ars de nomine et verbo proves that the use of the direct object in the impersonal passive constructions was possible in Late Latin.

\section{References}

Barwick K. (ed.) Flauii Sosipatri Charisii Artis grammaticae libri V. Leipzig, Teubner, 1964.

Calboli G. Studi Grammaticali. Bologna, Zanichelli, 1962.

Cennamo M. Impersonal Constructions and Accusative Subjects in Late Latin, in: A. Malchukov, A. Siewerska (eds). Impersonal Constructions: A Cross-Linguistic Perspective. Amsterdam, John Benjamins, 2011, 169-189.

Comrie B. In Defence of Spontaneous Demotion: The Impersonal Passive, in: Cole P., Sadock J.M. (eds). Syntax and Semantics. Vol. 8. Grammatical Relations. New York, Academic Press, 1977, 47-58.

Ernout A. Recherches sur l'emploi du passif latin à l'époque républicaine. Mémoire de la Société de Linguistique de Paris 1908-1909, 15, 273-333.

Goetz G. Consentius (Grammarian), in: RE 1900, IV/1, 911-912.

Goetz G. (ed.) M. Terentii Varronis Rerum Rusticarum Libri Tres. Leipzig, Teubner, 1929.

Hartung H. Die grammatische Theorie der Verba impersonalia: Einige Bemerkungen zu ihrer Entstehung und Entwicklung. RhMP 1975, 118, 3/4, 345-362.

Holtz L.(ed.) Donat et la tradition de l'enseignement grammatical, Étude sur l'Ars Donati et sa diffusion (IVe - IXe siècle) et édition critique. Paris, CNRS, 1981.

Jocelyn H. D. (ed.) The Tragedies of Ennius. Cambridge, CUP, 1967.

Kauer R., Lindsay W. M., Scutsch O. (eds). P. Terenti Afri Comoediae. Oxford, OUP, 1958.

Keil H. (ed.) Grammatici Latini. Vol. 5. Leipzig, Teubner, 1923.

Law V. Late Latin Grammars in the Early Middle Ages: A Typological History, in: Taylor D. J. (ed.) The History of Linguistics in the Classical Period. Amsterdam, John Benjamins, 1987.

Lindsay W. M. Syntax of Plautus. New York, G. E. Stechert \& Co, 1936.

Mynors R. A. B. (ed.). P. Vergilii Maronis Opera. Oxford, OUP, 1969.

Nixon P. (ed., transl.) Plautus, Vol.II: Casina. The Casket Comedy. Curculio. Epidicus. The two Menaechmuses. London, William Heinemann - New York, G. P. Putnam's sons, 1917.

Passalacqua M. (ed.) Tre testi grammaticali Bobbiesi. GL V, 555-566; 634-654, GL IV, 207-216 Keil. Roma, Edizioni di storia e letteratura, 1984.

Pinkster H. The Latin Impersonal Passive. Mnemosyne 1992, 45, 159-177.

Pinkster H. The Oxford Latin Syntax. Volume I: The Simple Clause. Oxford, OUP, 2015.

Ribbek O. (ed.) Comicorum Romanorum fragmenta. Leipzig, Teubner, 1898.

Received: August 19, 2018

Accepted: October 18, 2018

\section{К вопросу о прямом дополнении в латинских конструкциях с безличным пассивом}

Влада Александровна Чернымева

Санкт-Петербургский государственный университет, Российская Федерация, 199034, Санкт-Петербург, Университетская наб., 7-9; st042939@student.spbu.ru, chernyshe.va@mail.ru

Статья посвящена интерпретации безличных пассивных конструкций и глагольного управления у римских грамматиков. Прямое дополнение при безличных пассивных 
глаголах в классическом латинском языке не засвидетельствовано, тем не менее оно возможно в раннем и позднем периодах его развития и трактуется как разговорная черта. Полагаю, что пассаж, посвященный пассивным глаголам, в Ars de nomine et verbo (GL 5, 372, 35-373, 20) грамматика Консенция (V в. н.э.), содержит свидетельство употребления такого прямого дополнения. В нем, среди прочего, рассматриваются цитаты из Теренция (per quem res geretur maxime), Цицерона (rem agi) и Вергилия (iam tempus agi res), смысл которых остается неясным для Консенция. В примерах, разбираемых грамматиком, пассивные по форме глаголы geretur и agi истолковываются как в пассивном, так и в безличном смысле. В последнем случае существительные res и rem неизбежно становятся прямыми дополнениями. Однако по правилам грамматики классического латинского языка глаголы в цитируемых предложениях не могут иметь безличного значения, следовательно, формы существительного res являются подлежащими придаточного предложения и инфинитивных оборотов. Таким образом, разбираемый в данной статье пассаж из позднеантичной грамматики Ars de nomine et verbo пополняет перечень свидетельств, относящихся к V в. н.э., где прямое дополнение зависит от безличных пассивных глаголов. Кроме того, пассаж из Консенция интересен наложением разговорной черты на стандартные классические тексты, используемые в римской школьной практике.

Ключевые слова: латинская лингвистика, безличный пассив, глагольное управление, прямое дополнение, поздняя латынь, Консенций, римские грамматики. 